\title{
A VOLTAMMETRIC TECHNIQUE USING A MODIFIED CARBON PASTE ELECTRODE FOR THE DETERMINATION OF ACLONIFEN
}

\author{
WOLTAMPEROMETRYCZNE OZNACZANIE AKLONIFENU WĘGLOWĄ \\ ELEKTRODĄ PASTOWĄ ZA POMOCĄ FOSFORANU TRIKREZYLU
}

\begin{abstract}
A method for the determination of aclonifen at a carbon paste electrode modified with tricresyl phosphate has been developed. The optimum electrochemical regime proved to be differential pulse voltammetry (DPV) in the negative potential range from -200 to $-1600 \mathrm{mV}$. The optimum $\mathrm{pH}$ for the determination proved to be $\mathrm{pH}=8$. The calibration dependence is linear and the limit of detection achieved for the method was $2 \cdot 10^{-6} \mathrm{~mol} / \mathrm{dm}^{3}$. The method is fast, reliable and it is suitable for the detection of aclonifen in the concentration range from $2 \cdot 10^{-6}$ to $1 \cdot 10^{-4} \mathrm{~mol} / \mathrm{dm}^{3}$.
\end{abstract}

Keywords: voltammetry, carbon paste electrode, aclonifen, herbicide determination

\section{Introduction}

Aclonifen belongs to the diphenyl ether herbicide ( $\mathrm{DPhEH})$ group, this group includes many potent herbicides with a photodependent capability to inhibit protoporphyrinogen oxidase [1, 2]. Aclonifen is also a carotenoid synthesis inhibitor [3]. The substances from this group do not exhibit high acute toxicity, but posses such adverse effects as teratogenity [4], endocrine disrupting behavior [5,6] and some are mutagenic [7] and even suspected carcinogens [8]. Aclonifen is used frequently for the protection of soybeans, corn, sunflowers, tomatoes and various other crops against weeds [9, 10]. It is registered for use in many countries [11]. The use of herbicides is essential to obtaining high crop yields in modern agriculture, but unfortunately also has its side effects. It is therefore crucial to develop potent and reliable methods for their determination in the environment in trace levels. Voltammetric methods using novel electrode materials have proved to be extremely useful in this regard [12, 13]. A carbon-paste electrode (CPE) is made from a mixture of conducting graphite powder and a pasting liquid confined to a suitable electrode body. It was first thought of as an alternative to a dropping mercury electrode capable of oxidations,

\footnotetext{
${ }^{1}$ Institute for Nanomaterials, Advanced Technology and Innovation, Bendlova 1407/7, 46117 Liberec, Czech Republic, phone +420485353876

${ }^{2}$ Department of Analytical Chemistry, UNESCO Laboratory of Environmental Electrochemistry, Faculty of Science, Charles University of Prague, Hlavova 2030, Praha 2, Czech Republic

*Corresponding author: vit.novotny@tul.cz
} 
which was achieved much later [14]. The usual material nowadays is spectroscopic graphite [15], but other options exist [16-19]. In this work we use carbon microspheres, because of their good resistance to organic solvents [20]. These electrodes are simple to make and offer an easily renewable surface for electron exchange. The electrodes are used mainly for voltammetric measurements but are applicable in other areas of electrochemistry [21]. In general, CPEs are popular because carbon pastes are easily obtainable at minimal costs and are especially suitable for preparing electrode materials modified with additives giving the electrode new desired properties. The characteristic properties of carbon paste electrodes are their heterogeneity, lipofility, high conductivity and a favorable signal-to-noise ratio. The modification of carbon pastes represents a unique feature.

In contrast to the relatively complicated modifications of solid substrates, carbon pastes can be modified very easily to obtain new sensors with predefined properties. There are several ways of CPE modification. One way of changing the properties of the electrodes is a careful choice of the carbon type and pasting liquid. For instance, polarisation limits of a CPE can be controlled effectively simply by the choice of the binder, where tricresyl phosphate-based carbon paste can offer extreme polarisation limits [21] and could be polarised from -2 to $+2 \mathrm{~V}$ in an ammonia buffer [15]. Such performance is impossible for CPEs from Nujol and silicone oils and it is atypically broad for any electrode in aqueous media [22]. This material was used in this work, because despite having an aromatic amino group aclonifen proved to yield no oxidation signal of analytical value. Carbon pastes can be modified chemically by substances helping to preconcentrate the analyte in the paste, such as ion pairning agents, molecular imprinted polymers, cyclodextrins etc. Also the analyte can be mixed into the paste to investigate its electrochemical properties in a quasi-solid state electrochemical arrangement. Regarding biologically modified variants, the most frequent term for their reference is carbon paste biosensors. Carbon paste electrodes are convenient for the preparation of carbon paste-based biosensors because enzymes together with appropriate mediators can be easily mixed into the electrode material. Among modifiers used, one can find single compounds [23], sophisticated chemical agents [24], special inorganic materials [25], or even living tissues [26]. One of the fundamental pretreatments of a CPE is anodic activation. This is done by applying a positive potential on the electrode for a period of time. This causes the formation of carbonyl groups on the surface of the carbon, which then get protonized. The positive charge on the surface of the electrode repels the lipophilic binder and makes the electrode behave more like a solid carbon electrode. Although rarely mentioned in the literature, cathodic activation of the electrode can also be performed and results in a substantial decrease of the background current of the electrode [16]. Hg- and Au-film plated CPEs may provide a performance similar to that of other carbon or metallic electrodes commonly used for electrolytic accumulations (glassy carbon, HMDE, platinum or gold disk). Extraction of non-polar substances onto the electrode bulk can sometimes be a useful way of analyte preconcentration but if unwanted it may sometimes hinder reproducibility. Extraction processes at carbon pastes are governed by differences in solubility of extracted species in liquid binder and the respective aqueous phase (supporting electrolyte solution). Extractions at CPEs can be combined with adsorption and ion-pair formation. Common paraffin- and silicone oil containing carbon pastes offer no ion-pairing capabilities. Carbon paste mixtures made from tricresyl phosphate (TCP-CPE) are much more convenient in this regard. The recent focus in CPE research is on using fullerenes, carbon nanotubes [27] and 
other nanomaterials, also calixarenes, metallothioneins [28], or Ru-(bipyridil) coordination compound based additives [29] are popular.

\section{Chemicals}

The stock solution $\left(c=1 \cdot 10^{-3} \mathrm{~mol} \cdot \mathrm{dm}^{-3}\right)$ of Aclonifen (2-chloro-6-nitro-3phenoxybenzenamine 99\%, Sigma-Aldrich Laborchemikalien, Germany) has been prepared by dissolving $0.02648 \mathrm{~g}$ of AC in $100 \mathrm{~cm}^{3}$ of methanol. Solutions of lower concentrations were prepared by precise diluting of the stock solution with methanol. The stock solution was kept in the refrigerator. The stability of the stock solution was checked by UV-VIS spectrophotometric measurements. The stock solution was stable for at least 6 months under the conditions in which it was kept. Deionized water (Millipore, USA) was used as a solvent. Other used chemicals were boric acid (crystallized, extra pure Merck, Darmstadt, Germany) sodium hydroxide (97\% Tekkim Kimya Sanayi ve Ticaret Ltd. Şti., Turkey) glacial acetic acid $\left(99.8 \%\right.$ BDH Analar Limited Poole, England) phosphoric acid $\mathrm{H}_{3} \mathrm{PO}_{4}$ (85\% Birpa LTD. Şti. Ankara, Turkey) carbon microspheres 0.4-12 $\mu \mathrm{m}$ diameter (Alpha Aesar, USA), tricresyl phosphate, technical purity, mixture of isomers (Fluka, United Kingdom) and methanol p.a. (Merck, Darmstadt, Germany) were used. Britton-Robinson buffers of the desired $\mathrm{pH}$ were prepared by mixing of $0.2 \mathrm{~mol} \cdot \mathrm{dm}^{-3} \mathrm{NaOH}$ with a solution containing $0.04 \mathrm{~mol} \cdot \mathrm{dm}^{-3}$ boric acid, phosphoric acid and acetic acid.

\section{Apparatus}

Measurements of $\mathrm{pH}$ were performed on a Jenway 3510 (Jenway, Essex, Great Britain) pH-meter with a combined glass membrane electrode (type 924 005). The electrode was calibrated by standard buffer solutions in water. Palmsens Electrochemical Sensor Interface (Palm Instruments BV, Ruitercamp, The Netherlands) and the PalmsensPC software were used for all voltammetric measurements. The software was running under the Windows XP (Microsoft Corp.) operating system. Pulses of width of $80 \mathrm{~ms}$ and height of $-50 \mathrm{mV}$ were used while performing DPV. A polarization rate of $20 \mathrm{mV} / \mathrm{s}$, and potential resolution of $5 \mathrm{mV}$ were used. All measurements were performed using a three electrode system. A carbon paste working electrode, a platinum wire auxiliary electrode and a silver chloride electrode $\left(1 \mathrm{~mol} \cdot \mathrm{dm}^{-3} \mathrm{KCl}\right)$ type RAE 113 , Monokrystaly, Turnov, Czech Republic.

\section{Procedures}

To prepare the carbon paste, $250 \mathrm{mg}$ carbon microspheres $0.4-12 \mu \mathrm{m}$ diameter (Alpha Aesar, USA) were mixed with $100 \mathrm{~mm}^{3}$ tricresyl phosphate (technical purity, mixture of isomers, Fluka, United Kingdom) in a mortar with a pestle [19]. The mixture was then transferred with a spatula into the Teflon electrode body. The inner diameter of the used body was $3 \mathrm{~mm}$. Prior to each measurement approximately $0.1 \mathrm{~mm}$ of electrode was wiped on a filter paper and each measurement was performed on a freshly wiped surface to prevent passivation. Measured solutions of AC were prepared by adding an appropriate amount of the stock solution to a $10 \mathrm{~cm}^{3}$ volumetric flask, filling with methanol to a volume of $5 \mathrm{~cm}^{3}$ and then filling the flask up to $10 \mathrm{~cm}^{3}$ with BR buffer of the desired $\mathrm{pH}$. Values of points in calibration curves are arithmetic averages of 3 measurements. Error bars are derived from the same data. Detection limits are calculated according to the formula $L_{\mathrm{D}}=3.3 \cdot \sigma / S$, where 
$\sigma$ is the standard deviation of 10 measurements of the lowest concentration for which the signal can still be evaluated and $S$ is the slope of calibration curve in the vicinity of the lowest concentration [30].

\section{Results}

Anodic DPV of aclonifen was attempted because the substance has an aromatic amino group, but the signal that oxidation of the substance yields was negligibly small and therefore of no analytical use. Using cathodic DPV, the substance yields a single peak in the whole $\mathrm{pH}$ range. The peak potential; shifts towards increasingly negative values (Fig. 1).

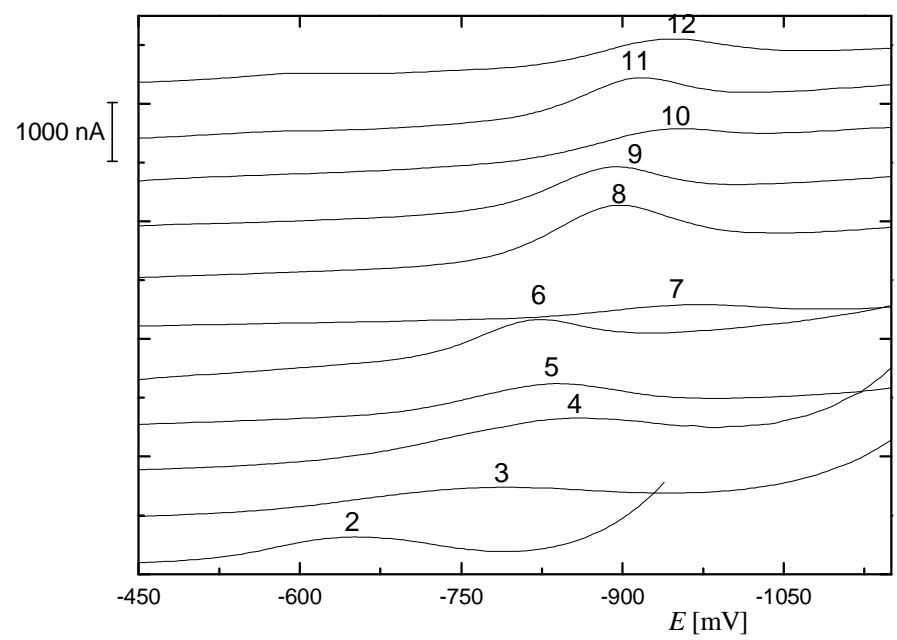

Fig. 1. DP voltammograms of $\mathrm{AC}\left(c=10^{-4} \mathrm{~mol} \cdot \mathrm{dm}^{-3}\right)$ at TCP CPE in a solution of a mixture of BR Buffer and methanol (1:1). Br buffer pH 2 (1), 3 (2), 4 (3), 5 (4), 6 (5), 7 (6), 8 (7), 9 (8), 10 (9), 11 (10) and $12(11)$

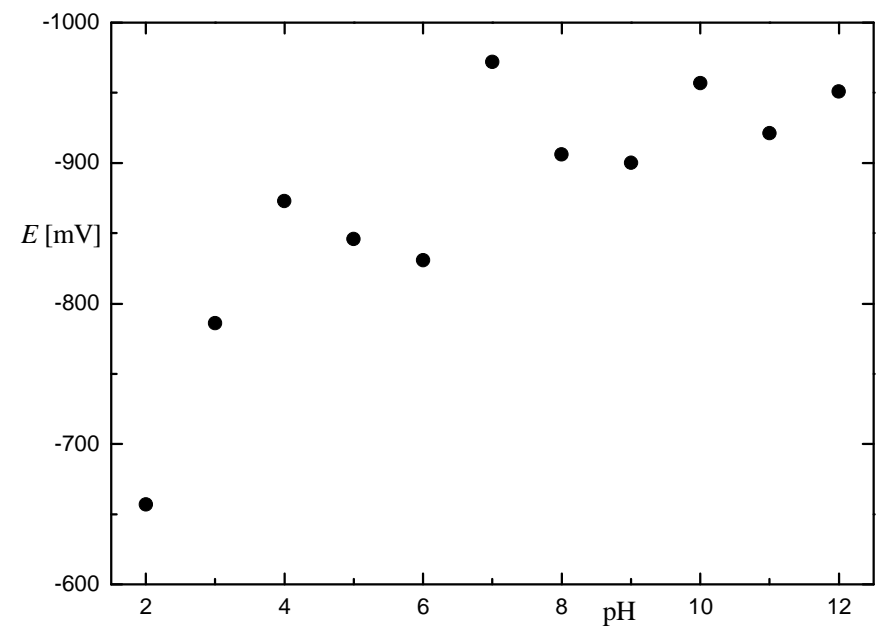

Fig. 2. The dependence of the peak potential on $\mathrm{pH}$ of the peaks of AC $\left(c=10^{-5} \mathrm{~mol} \cdot \mathrm{dm}^{-3}\right)$ at TCP CPE in a solution of BR Buffer - MeOH (1:1) 


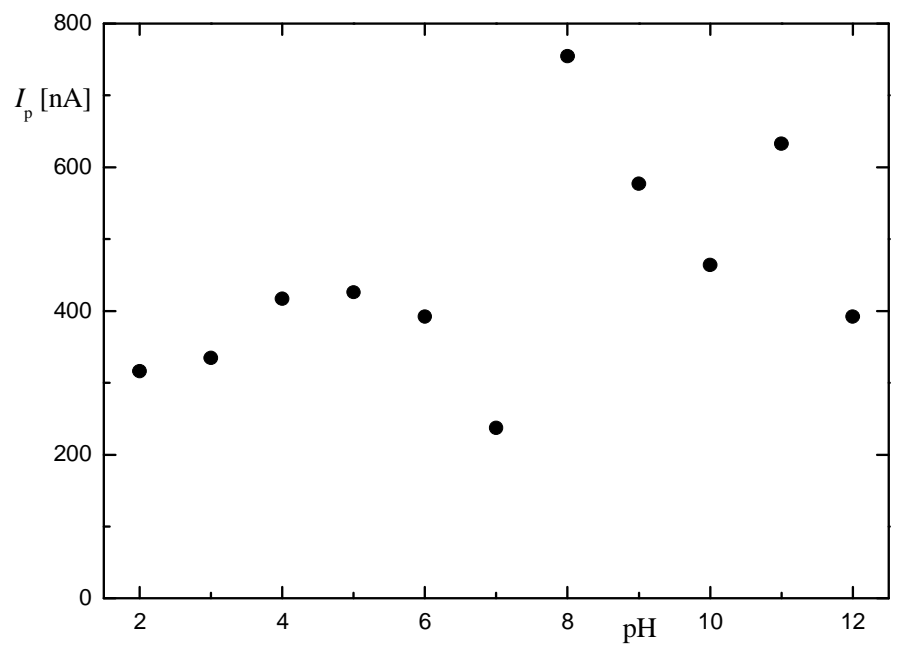

Fig. 3. The dependence of the peak height of AC $\left(c=10^{-5} \mathrm{~mol} \cdot \mathrm{dm}^{-3}\right)$ on $\mathrm{pH}$. Measured on TCP CPE in a solution of BR Buffer with the desired $\mathrm{pH}-\mathrm{MeOH}(1: 1)$

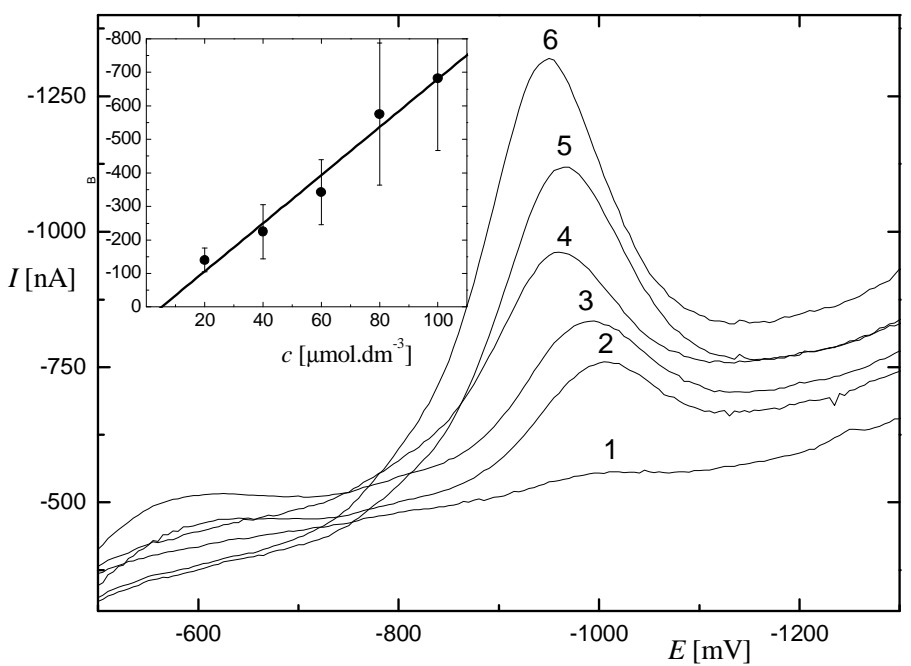

Fig. 4. DP voltammograms of $\mathrm{AC}$ at TCP CPE in a solution of BR Buffer pH $8-\mathrm{MeOH}(1: 1)$. AC concentration 0 (1) 20 (2), 40 (3), 60 (4), 80 (5) and $100 \mu \mathrm{mol} \cdot \mathrm{dm}^{-3}$ (6). The error bars denote the standard deviations of three measurements

The peak height fluctuates, and the general trend is that it increases with increasing $\mathrm{pH}$, but the highest peak height was obtained for $\mathrm{pH} 8$ (Figs. 2, 3). This value was therefore chosen for measuring the calibration sequence. The calibration curve is linear in the concentration range $(2-10) \cdot 10^{-5} \mathrm{~mol} \cdot \mathrm{dm}^{-3}$ (Fig. 4). The parameters of the calibration curves are summarized in Table 1.

The corresponding calibration dependence is in the inset. 
The parameters of calibration straight lines of Aclonifen in BR buffer $\mathrm{pH} 8$ determined by DPV at a CPE in the concentration range from $2 \cdot 10^{-6}$ to $10 \cdot 10^{-5} \mathrm{~mol} \cdot \mathrm{dm}^{-3}$

\begin{tabular}{|c|c|c|c|c|c|}
\hline $\begin{array}{c}\boldsymbol{c}(\mathbf{A C}) \\
{\left[\mathbf{m o l} \cdot \mathbf{d m}^{-3}\right]}\end{array}$ & $\begin{array}{c}\boldsymbol{S} \\
{\left[\mathbf{n A} \cdot \mathbf{d m}^{\mathbf{3}} \cdot \mathbf{m o l}^{\mathbf{- 1}}\right]}\end{array}$ & $\begin{array}{c}\text { Intercept } \\
{[\mathbf{n A}]}\end{array}$ & $\boldsymbol{\sigma}[\mathbf{n A}]$ & $\boldsymbol{R}$ & $\begin{array}{c}\boldsymbol{L}_{\mathbf{D}} \\
{\left[\mathbf{m o l}^{-} \cdot \mathbf{d m}^{-3}\right]}\end{array}$ \\
\hline$(2-10) \cdot 10^{-5}$ & $-7.18 \cdot 10^{6}$ & 37.6 & 58.1 & -0.9861 & $3 \cdot 10^{-5}$ \\
\hline$(2-10) \cdot 10^{-6}$ & $-9.86 \cdot 10^{6}$ & -21.5 & 32.5 & -0.9019 & $1 \cdot 10^{-5}$ \\
\hline
\end{tabular}

\section{Conclusions}

The method of determination of Aclonifen at a carbon paste electrode using carbon microspheres as the electrode material and tricresyl phosphate as the pasting liquid has been developed. The mode used was differential pulse voltammetry in the cathodic mode, as oxidation of Aclonifen was attempted without success. Cathodic voltammetry makes the use of tricresyl phosphate and carbon microspheres essential. The detection limit reached is $1 \cdot 10^{-5} \mathrm{~mol} \cdot \mathrm{dm}^{-3}$ and the calibration dependence is linear in the concentration range from $2 \cdot 10^{-6}$ to $1 \cdot 10^{-4} \mathrm{~mol} \cdot \mathrm{dm}^{-3}$. The detection limit is quite high so using a cleanup and preconcentration method for the determination of Aclonifen in model samples in conjunction with voltammetry is necessary and will be the focus of our future work.

\section{Acknowledgements}

Financial support of this work, provided by the Grant Agency of Czech Republic (project P206/12/G151) is gratefully acknowledged.

\section{References}

[1] Choi JS, Lee HJ, Hwang IT, Pyon JY, Cho KY. Differential susceptibilities of wheat and barley to diphenyl ether herbicide oxyfluorfen. Pestic Biochem Physiol. 1999;65(1):62-72. DOI: 10.1006/pest.1999.2429.

[2] Graham MY. The diphenylether herbicide lactofen induces cell death and expression of defense-related genes in soybean. Plant Physiol. 2005;139(4):1784-1794. DOI: 10.1104/pp.105.068676.

[3] Kilinc O, Reynaud S, Perez L, Tissut M, Ravanel P. Physiological and biochemical modes of action of the diphenylether aclonifen. Pestic Biochem Physiol. 2009;93:65-71. DOI: 10.1016/j.pestbp.2008.11.008.

[4] Francis BM, Metcalf RL, Lewis PA, Chernoff N. Maternal and developmental toxicity of halogenated 4'-nitrodiphenyl ethers in mice. Teratology. 1999;59:69-80. DOI: 10.1002/(SICI)1096-9926(199902)59:2.

[5] Hong C-C, Shimomura-Shimizu M, Muroi M, Tanamoto K-I. Effect of endocrine disrupting chemicals on lipopolysaccharide-induced tumor necrosis factor-a and nitric oxide production by mouse macrophages. Biol Pharmacol Bull. 2004;27(7):1136-1139.

[6] Mastorakos G, Karoutsou EI, Mizamtsidi M, Creatsas G. The menace of endocrine disruptors on thyroid hormone physiology and their impact on intrauterine development. Endocrine. 2007;31:219-237. DOI: 10.1007/s12020-007-0030-y.

[7] Draper WM, Casida JE. Diphenyl ether herbicides and related compounds: structure-activity relationships as bacterial mutagens. J Agric Food Chem. 1983;31:1201-1207. DOI: 10.1021/jf00120a015.

[8] Milman HA, Ward JM, Chu KC. Pancreatic carcinogenesis and naturally occurring pancreatic neoplasms of rats and mice in the NCI carcinogenesis testing program. J Environ Pathol Toxicol Oncol. 1978: 829-840.

[9] Vischetti C, Marucchini C, Leita L, Cantone P, Danuso F, Giovanardi R. Behaviour of two sunflower herbicides (metobromuron, aclonifen) in soil. Eur J Agronomy. 2002;16:231-238. DOI: 10.1016/S1161-0301(01)00136-8.

[10] Trevisan M, Capri E, Cella A, Errera G, Sicbaldi F. Field, laboratory and modelling studies to evaluate Aclonifen soil fate. Toxicol Environ Chem. 1999;70:29-47. DOI: 10.1080/02772249909358737.

[11] Covarelli L, Tosi L. Presence of sunflower downy mildew in an integrated weed control field trial. J Phytopathol. 2006;154:281-285. DOI: 10.1111/j.1439-0434.2006.01094.x. 
[12] Fischer J, Dejmkova H, Barek J. Electrochemistry of pesticides and its analytical applications. Current Organic Chem. 2011;15:2923-2935. DOI: 10.2174/138527211798357146.

[13] Dordevic J, Papp Z, Guzsvány V, Švancara I, Trtic-Petrovic T, Purenovic M, et al. Voltammetric determination of the herbicide linuron using a tricresyl phosphate-based carbon paste electrode. Sensors. 2012;12(1):148-161.

[14] Tatsumi H, Shiba M. Polarography with a dropping carbon electrode. Electrochem Commun. 2012;20(0):160-162. DOI: 10.1016/j.elecom.2012.04.021.

[15] Svancara I, Vytras K. Voltammetry with carbon paste electrodes containing membrane plasticizers used for PVC-based ion-selective electrodes. Anal Chim Acta. 1993;273:195-204. DOI: 10.1016/0003-2670(93)80158-H.

[16] Svancara I, Hvizdalova M, Vytras K, Kalcher K, Novotny R. A microscopic study on carbon paste electrodes. Electroanalysis. 1996;8(1):61-65 DOI: 10.1002/elan.1140080113.

[17] Zarbin A. Nanomaterials chemistry. Quim Nova. 2007;30(6):1469-1479. DOI: 10.1590/S0100-40422007000600016.

[18] Nemcova L, Barek J, Zima J. A voltammetric comparison of the properties of carbon paste electrodes containing glassy carbon microparticles of various sizes. J Electroanal Chem. 2012;675(0):18-24. DOI: 10.1016/j.jelechem.2012.04.019.

[19] Apetrei C, Apetrei IM, De Saja JA, Rodriguez-Mendez ML. Carbon paste electrodes made from different carbonaceous materials: Application in the study of antioxidants. Sensors (Basel, Switzerland). 2011;11(2):1328-1344.

[20] Dejmkova H, Zima J, Barek J, Mika J. Behavior of glassy carbon paste electrode in flowing methanolic solutions. Electroanalysis. 2012;24(8):1766-1770. DOI: 10.1002/elan.201100598.

[21] Tian Y, Han S, Hu L, Yuan Y, Wang J, Xu G. Cathodic electrochemiluminescence and reversible electrochemistry of $[\mathrm{Ru}(\mathrm{bpy}) 3] 2+/ 1+$ in aqueous solutions on tricresyl phosphate-based carbon paste electrode with extremely high hydrogen evolution potential. Anal Bioanal Chem. 2013;405(11):3427-3430. DOI: 10.1007/s00216-012-6032-5.

[22] Svancara I, Vytras K, Barek J, Zima J. Carbon paste electrodes in modern electroanalysis. Crit Rev Anal Chem. 2001;31(4):311-346 .DOI: 10.1080/20014091076785.

[23] Soltani N, Haddadi H, Asgari M, Semnani A. Stripping voltammetric detection of thorium on the oxine modified carbon paste electrode. J Radioanal Nucl Chem. 2015;304(2):603-607. DOI: 10.1007/s10967-014-3837-z.

[24] Soltani N, Tavakkoli N, Ahmadi N, Davar F. Simultaneous determination of acetaminophen, dopamine and ascorbic acid using a $\mathrm{PbS}$ nanoparticles Schiff base-modified carbon paste electrode. Comptes Rendus Chimie. 2015;18(4):438-448. DOI: 10.1016/j.crci.2014.07.001.

[25] Ibrahim H, Temerk Y. Novel sensor for sensitive electrochemical determination of luteolin based on $\operatorname{In}_{2} \mathrm{O}_{3}$ nanoparticles modified glassy carbon paste electrode. Sensors and Actuators B: Chemical. 2015;206(0):744-752. DOI: 10.1016/j.snb.2014.09.011.

[26] Aigner M, Telsnig D, Kalcher K, Teubl C, Macheroux P, Wallner S, et al. Amperometric biosensor for total monoamines using a glassy carbon paste electrode modified with human monoamine oxidase $\mathrm{B}$ and manganese dioxide particles. Microchim Acta. 2015;182(5-6):925-931. DOI: 10.1007/s00604-014-1404-5.

[27] Rivas GA, Rubianes MD, Pedano ML, Ferreyra NF, Luque GL, Rodríguez MC, et al. Carbon nanotubes paste electrodes. A new alternative for the development of electrochemical sensors. Electroanalysis. 2007;19(7-8):823-831. DOI: 10.1002/elan.200603778.

[28] Sestakova I, Kopanica M, Havran L, Palecek E. Constant current chronopotentiometric stripping analysis of cd-metallothionein on carbon and mercury electrodes. comparison with voltammetry. Electroanalysis. 2000;12(2):100-104. DOI: 10.1002/(SICI)1521-4109(200002).

[29] Xu G, Dong S. Electrochemiluminescence of the Ru(bpy)32+/S2O82- system in purely aqueous solution at carbon paste electrode. Electroanalysis. 2000;12(8):583-587. DOI: 10.1002/(SICI)1521-4109(200005).

[30] Hayashi Y, Matsuda R, Ito K, Nishimura W, Imai K, Maeda M. Detection limit estimated from slope of calibration curve: An application to competitive ELISA. Anal Sci. 2005;21:167-169. DOI: 10.2116/analsci.21.167. 


\section{WOLTAMPEROMETRYCZNE OZNACZANIE AKLONIFENU WĘGLOWA ELEKTRODĄ PASTOWĄ ZA POMOCĄ FOSFORANU TRIKREZYLU}

Abstrakt: Opisano metodę oznaczania aklonifenu węglową elektrodą pastową, modyfikowaną za pomocą fosforanu trikrezylu. Optymalnym systemem elektrochemicznym w badanej metodzie jest woltamperometria pulsowo-różnicowa (DPV) w ujemnym zakresie napięć od -200 do $-1600 \mathrm{mV}$. Optymalne pH badanej metody wynosi 8 . Krzywa kalibracyjna ma charakter liniowy z granicą wykrywalności $2 \cdot 10^{-6} \mathrm{~mol} / \mathrm{dm}^{3}$. Opisana metoda jest szybka, niezawodna oraz przydatna do oznaczania aklonifenu w zakresie stężeń od $2 \cdot 10^{-6}$ do $1 \cdot 10^{-4} \mathrm{~mol} / \mathrm{dm}^{3}$.

Słowa kluczowe: woltamperometria, węglowa elektroda pastowa, aklonifen, oznaczanie herbicydów 